Zdzisław Pawłowski

UMK, Toruń

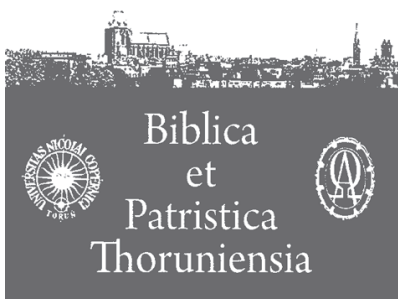

$4(2011)$

ISSN 1689-5150

\title{
Próba Abrahama Lektura narracyjna Rdz 22
}

\section{The Test of Abraham The Narrative Reading of Genesis 22}

Słowa kluczowe: Abraham, Izaak, próba, ofiara, fabuła, dialog, moment przełomowy (perypetia) rozpoznanie (anagnorisis), przekaz wiary, substytucja, rytuał przejścia.

Key words: Abraham, Isaac, test, offering, plot, dialogue, turning point, recognition, handing down faith, substitution, ritual of passage.

$\mathrm{O}$ powiadanie w Rdz 22,1-19 jest bardziej znane pod innymi tytułami ${ }^{1}$. Tradycja żydowska określa je mianem „Związanie” (Akeda), natomiast chrześcijańska mówi o „Ofiarowaniu Izaaka”. Każdy z nich sugeruje odmienny rodzaj lektury. Obydwie jednak starają się skupić uwagę czytelników na samym akcie złożenia ofiary, przez co akcentują gotowość Abrahama do poświęcenia Bogu tego, co miał najcenniejsze - swego jedynego syna. Wszelako od czasów Kanta aż do dzisiaj ten model interpretacji wzbudza głęboki sprzeciw i dla wielu jest jednym z powodów odrzucenia religii w ogóle. Warto więc przytoczyć jego argumenty, odnoszące się bezpośrednio do tego epizodu, które umieścił w swojej ostatniej pracy Spór fakultetów: „Istnieją przypadki, w których człowiek może być przekonany, że to nie może być Bóg, którego głos jak sądzi słyszy. Kiedy głos rozkazuje mu zrobić to, co jest przeciwne prawu moralnemu, wtedy choć samo

1 Granice tego epizodu dość łatwo określić, choć dwukrotna przemowa posłańca PANA, skierowana do Abrahama w Rdz 22,11-12 i 22,15-18 może sugerować złożony proces powstania całego opowiadania. Pierwotna wersja mogła kończyć się w Rdz 22,14, do której prawdopodobnie później dodano ww. 15-19 jako swoistego rodzaju dopowiedzenie, zaadresowane bezpośrednio do czytelników. Tym niemniej, w swojej aktualnej postaci opowieść tworzy zamkniętą całość, wyodrębnioną od poprzedzających i następujących po nim epizodów za pomocą dwóch podobnych formuł w 22,1 i w 22,20. 
zjawisko może być wykraczające poza naturę, musi go uznać za oszustwo. Abraham powinien odpowiedzieć na ów domniemany głos Boży: „Jest dla mnie całkiem pewne, że nie zabiję mojego umiłowanego syna, natomiast nie jestem wcale pewien, że ty, który mi się ukazujesz, jesteś Bogiem”. Kant sytuuje wydarzenie opisane w Rdz 22 na planie moralności, która przyjęta jako założenie jego wykładni stanowi źródło trudności w zrozumieniu przesłania całego opowiadania i sprawia, że współczesna wrażliwość, mimo żarliwej obrony Abrahama podjętej w Bojaźni i drżeniu przez S. Kierkegaarda, z góry odrzuca możliwość zaakceptowania jego ślepego jak się zdaje posłuszeństwa niemoralnemu rozkazowi Boga ${ }^{2}$.

Lektura narracyjna obiera nieco inną drogę podejścia do tego tekstu. Proponuje czytelnikom, aby na moment zawiesili swoje uprzedzenia i byli gotowi bez pośpiechu i antycypujących ocen śledzić jego fabułę, w jej kolejnych rozwinięciach i przeobrażeniach. Antycypacje bowiem także w życiu nie pozwalają wydarzeniom przemówić własnym głosem, lecz tłumią je siłą własnych domysłów. W przypadku Rdz 22, spojrzenie czytającego zazwyczaj przeskakuje wszystko to, co dzieje się wcześniej, by z przerażeniem obserwować końcowy akt złożenia ofiary z syna. Lektura narracyjna pozwala również uniknąć pokusy typowo religijnych wyjaśnień, przyjmujących nader często wymiar teodycei. $\mathrm{W}$ swojej obronie Boga tracą one $\mathrm{z}$ oczu różne Jego obrazy występujące w Biblii, a także zawiłości losów i ambiwalentność motywów, którymi kierują się biblijni bohaterowie. Wbrew apologetom biblijne formy religijności dalekie są od czarno-białych uproszczeń.

A w opowiadaniach chodzi właśnie o badanie i śledzenie przebiegu fabuły. Ta ostatnia nie jest prostym, chronologicznym uszeregowaniem zdarzeń na modłę kroniki, w której nie ma zaznaczonego ani początku ani środka ani końca, wszystkie bowiem wydarzenia ukazane są w jednorodnym ciągu dat. Natomiast fabuła jest zróżnicowaną organizacją epizodów i okoliczności. Niektóre z nich stanowią zawiązanie akcji dramatycznej, tworząc jej początek, inne określają jej moment kulminacyjny w takim jej zawikłaniu, że czytelnik wydaje się całkowicie zdezorientowany i nie wie, jak dalej ona się potoczy. Wreszcie rozwiązanie wyjaśnia wszystko na końcu.

Kronika i fabuła to nie tylko dwie różne konwencje literackie, wykorzystywane do opisu zdarzeń. Do pewnego stopnia odzwierciedlają one również dwa odmienne sposoby życia, a ściślej, dwa różne wzorce konstruowania tożsamości osobowej. Można przecież przedstawić swoje życie i je przeżywać jak kronikę, dostrzegając wyłącznie daty i nie wyróżniając żadnego epizodu. Jednak

2 Por. M. Williams, Kant and Kierkegaard on Faith: In Service to Morality and a Leap for the Absurd, Logos, Fall (2004) 82-97, wersja elektroniczna: http://www.ntslibrary.com/PDF BooksII/ 
czyjeś losy mogą się toczyć jak opowieść z mniej lub bardziej interesującą intrygą. W Biblii tożsamość najbardziej znaczących postaci przyjmuje kształt fabuły. Dlatego trzeba śledzić dokładnie jej etapy, zwracając uwagę na szczegóły, które zwłaszcza w krótkich opowiadaniach o charakterze paradygmatycznym, mogą mieć niezwykle duże znaczenie.

\section{Struktura fabuły w Rdz 22,1-19}

Zarówno jej tematyczna orientacja, jak i jej religijne przesłanie, nie są łatwe do rozszyfrowania, nie tylko przy pierwszej i często pobieżnej lekturze, ale także po wielokrotnych odczytaniach. Trudności te związane są przede wszystkim ze złożonym i zawiłym, charakterem jej kompozycji, choć samo opowiadanie uderza prostotą i lakonicznością użytych w nim sformułowań. Zawiera ono dwie płaszczyzny, na których rozgrywa się jego fabuła. Pierwszą tworzą opisy zdarzeń i działań, które wyznaczają jej ramy czasowo-przestrzenne oraz determinują kierunek akcji dramatycznej, znajdującej swój moment kulminacyjny w złożeniu ofiary całopalnej z Izaaka. Druga składa się z dialogów, które spowalniają jej przebieg, i poprzez swoją wyjątkową formę retoryczną komplikują intrygę, przenosząc ją w sferę wewnętrznej tożsamości bohaterów $\mathrm{i}$ ich wzajemnych relacji.

Zestawienie tych dwóch płaszczyzn, opisu i dialogu w strukturze opowiadania jest tym bardziej uderzające, że dialogi z punktu widzenia dziejących się zdarzeń nie wnoszą niczego nowego, a w gruncie rzeczy są zbędne. Ich usunięcie nie narusza podstawowej konstrukcji fabuły, co więcej bez dialogów biegnie ona całkiem wartko i zrozumiale, $w$ stylu podobnych epizodów, opowiadających o zastąpieniu ofiar z ludzi (dzieci) ofiarami ze zwierząt (np. opowieść o Ifigenii) ${ }^{3}$. Rolą dialogów jest nie tylko sproblematyzowanie opisywanych zdarzeń, które w ich kontekście stają się zagadką do rozwiązania, ale także odwrócenie hierarchii ich wartościowania, które radykalnie zmienia spojrzenie na występujących tu bohaterów. Czytelnik ma w nich dostrzec nie tyle podmioty wyposażone w zdolność do działania, ile bardziej osoby zdolne do prowadzenia ze sobą rozmowy. Jak podkreśla Robert Alter: „Wszystko w świecie biblijnych opowiadań grawituje ostatecznie w kierunku dialogu [...], ponieważ dla starożytnych pisarzy hebrajskich mowa wydawała się najbardziej istotną z ludzkich predyspozycji, gdyż urzeczywistniając zdolność mówienia człowiek wykazywał, jakkolwiek w sposób niedoskonały, swoje podobieństwo do Boga"4.

3 Por. H. Ch. Brichto, The Names of God, Oxford 1998, 290-297.

4 The Art of Biblical Narrative, New York 1981, 182. 
W duchu tej tezy można zaryzykować stwierdzenie, iż to, co najważniejsze w tej opowieści, rozgrywa się nie na planie zdarzeń, lecz właśnie dialogów. Na tym też polega podstęp zastawiony na czytelników przez narratora. Skupiają się oni zwykle na przebiegu zdarzeń, przeskakując dialogi jako mało ważne, bo przecież Abraham ostatecznie wyszedł zwycięsko z próby, na którą został wystawiony: gotów był poświęcić nawet swego jedynego syna dla Boga, by udowodnić, że Boga kocha bardziej niż swoje dziecko. Tylko, że takie wyjaśnienie rodzi problemy zasygnalizowane przez Kanta: kim jest ten Bóg, że żąda od człowieka aż takiej ofiary, i dlaczego ojcu i synowi każe przejść przez tak traumatyczne doświadczenia?

Obecność i retoryczny kształt dialogów nie pozwalają zatem na obranie takiego kierunku interpretacji, wprowadzając dysonans w ten znany i raczej schematyczny rozwój zdarzeń. W opisach tych ostatnich, owszem, Abraham ukazany jest jako absolutny pan własnych czynności, rozpoczynających się standardową formułą „wstał wcześnie rano” (Rdz 22,3), podkreślających jego doskonałe posłuszeństwo Bożym poleceniom. Ale w żadnej mierze nie jest on panem dialogów: inicjuje je zawsze ktoś inny, a Abraham tylko odpowiada. Najpierw zwraca się doń Bóg, następnie Izaak a potem anioł PANA. Każdy $\mathrm{z}$ nich rozpoczynając rozmowę $\mathrm{z}$ Abrahamem narusza status quo jego świata. W Izaaku ma jedynego, upragnionego dziedzica. Po wielu perturbacjach wreszcie wszystko ułożyło się po jego myśli, i wydaje się, że nic odtąd nie powinno zburzyć błogostanu, którego dostąpił w późnej starości. A oto polecenie złożenia ofiary z Izaaka, ten, zdawałoby się stan definitywnych rozstrzygnięć, w którym już nic nie powinno się zmienić, zostaje wywrócony do góry nogami: znów, jak na początku Abraham ma pozostać bez dziedzica ${ }^{5}$. Z kolei w drodze na wzgórze, gdzie Izaak miał zostać złożony w ofierze, odzywa się on prostym słowem „ojcze mój”, na które odpowiada on „synu mój”. Czy w tej krótkiej acz pełnej emocjonalnego napięcia wymianie, odbywającej się w horyzoncie zbliżającego się aktu ofiarnego, Abraham jest jeszcze jego ojcem a Izaak - jego synem? W samym zaś zakończeniu anioł PANA słowem powstrzymuje jego rękę przed czynem, mającym potwierdzić jego posłuszeństwo Bogu, kwestionując je w ten sposób. Tak więc, to dialogi sprawiają, że czytelnik zaczyna się zastanawiać nad charakterem religii, która zostaje mu przedłożona w Rdz 22: kim jest ten Bóg, który ciągle komplikuje losy swoich oddanych czcicieli?

Zawikłanie fabuły pogłębia się jeszcze bardziej przez użycie różnych imion Boga. Występują nie tylko dwa imiona Elohim i Jahwe, ale pojawiają się także ich gramatyczne warianty niedostrzegalne w przekładach. Na początku oraz wyłącznie w stwierdzeniach narratora pojawia się HaElohim (Elohim z rodzaj-

5 Por. L. A. Turner, Genesis, Sheffield 2000, 97. 
nikiem). W środku, w rozmowie Izaaka z Abrahamem, występuje imię Elohim bez rodzajnika, jak również w zwrocie bojacy się Boga (Elohim). Wreszcie na końcu dwukrotnie spotykamy wyrażenie Malak Jahwe z nieba, który powstrzymuje rękę Abrahama i pod przysięgą składa mu obietnicę licznego potomstwa. Cała ta gra różnych imion Boga odbywa się w kontekstach dialogów lub w bezpośrednim związku z nimi, tym mocniej podkreślając ich wagę.

Ich dominującą rolę potwierdza jeszcze inny zabieg retoryczny. W niewielu narracjach biblijnych występuje taka koncentracja formuly wajjomer (powiedział). W 19 wierszach pojawia się ona aż 17 razy, czasami bez gramatycznego uzasadnienia, łamiąc reguły dobrego stylu. Jej wielokrotne zastosowanie odwraca spojrzenie czytelników od planu zdarzeń, nie pozwalając im na zbytni pośpiech w zaspokojeniu ciekawości, co stanie się dalej? Raczej każe się zatrzymać i badać, kto, do kogo, co, jak i dlaczego mówi. Usiłuje ona skupić uwagę czytelnika na wypowiadanych słowach, jakby cała fabuła rozgrywała się nie tyle na płaszczyźnie czynności, ile wypowiedzi, i to w takiej mierze, że te ostatnie zdają się zmieniać pozornie jasny sens tych pierwszych, powodując, iż końcowy efekt fabuły jest całkowicie zaskakujący.

$\mathrm{Na}$ podstawie powyższych obserwacji, dotyczących narracyjnych i retorycznych aspektów tekstu, jego kompozycja fabularna, wyznaczająca plan lektury, przedstawia się następująco.

Jako jedno z nielicznych opowiadań w Biblii, rozpoczyna się ono wyraźnie zaznaczonym nagłówkiem w wierszu $1^{6}$, po którym następuje zawiązanie akcji w ww. 1-3, obejmujące dialog Boga z Abrahamem (ww. 1-2) i opis czynności Abrahama (w. 3) ${ }^{7}$. Następnie fabuła przemilcza wydarzenia z trzydniowej drogi do krainy Moria, i już w nowych okolicznościach czasu i miejsca, rozwija się zgodnie z oczekiwaniami czytelników, zawierając tylko szczegółową listę działań Abrahama, bez jakiegokolwiek dialogu (ww. 4-6). Wszelako jego sytuację komplikuje kolejna rozmowa (ww. 7-8), tym razem zainicjowana przez Izaaka, $\mathrm{z}$ kluczowym dla całego opowiadania pytaniem tego ostatniego. $\mathrm{Z}$ jego perspektywy, czynności Abrahama, skoncentrowane na akcie złożenia ofiary ze swego syna (ww. 9-10), muszą zabrzmieć tragicznym i przerażającym tonem. Zwieńczający fabułę dialog (ww. 11-12), owszem przynosi rozwiązanie, zresztą

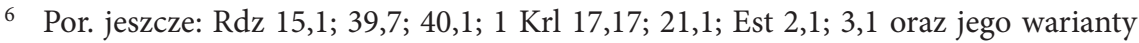
w Rdz 22,20; 48,1; Joz 24,29. Przy czym formuła ta w Rdz 22,20, różniąca się nieco od wyrażeń w Rdz 22,1 i 15,1 wyznaczając granicę poprzedniego epizodu i rozpoczynając nowy, sygnalizuje zarazem ich ścisłe powiązanie fabularne w ramach cyklu opowiadań o Abrahamie, por. I. Kalimi, «Go, I Beg You, Take Your Beloved Son and Slay Him!»: Binding of Isaac in Rabbinic Literature and Thought, ,Review of Rabbinic Judaism” 13 (2010) 6-7.

7 Tak więc, już na samym początku zaznaczone jest pierwszeństwo mowy przed działaniem. 
oczekiwane przez czytelników, wyjaśniające sens próby, której został poddany Abraham, ale nie zaciera wcale traumatycznego doświadczenia, które musieli przeżyć ojciec i syn przy składaniu ofiary8. Dopiero w jego świetle można zrozumieć znaczenie kolejnych czynności Abrahama (ww. 13-14), szczególnie znaczenie zamiany jednej ofiary na drugą: baran zamiast syna. Opowieść jednak nie kończy się na tym. Anioł PANA (Malak Jahwe) przemawia do Abrahama po raz drugi, ale jego słowa skierowane są bardziej do czytelników niż do niego, tworząc swoistego rodzaju koda albo postscriptum (ww. 15-18), po którym następuje opis powrotu Abrahama do domu, równie zagadkowy i dający wiele do myślenia, bo naznaczony piętnem przemilczenia, a raczej nieobecności (w. 19).

\section{Lektura fabuły w Rdz 22,1-19}

Doskonale skomponowana fabuła, zwłaszcza w opowiadaniach dobrze znanych, a więc podatnych na wszelkie skutki wyczerpywania się sensu i reakcję znudzenia ze strony czytelników, charakteryzuje się tym, że nawet podczas wielokrotnych odczytywań wywołuje za każdym razem ciągle odnawiające się napięcie. Jednakże, nie jest ono związane z pytaniem, „co dalej?”, odnoszącym się do prostych historii, które dają się czytać tylko raz, gdyż przy kolejnym przestają wzbudzać ciekawość, bo wszystko w nich jest jasne. W lekturze biblijnych opowiadań chodzi zawsze o poszukiwanie odpowiedzi na pytanie „dlaczego?”. To ostatnie nie pochodzi od czytelnika, lecz wyłania się z retoryki tekstu, która od samego początku czyni go tajemniczym. W Rdz 22 enigmatycznie brzmi już sam nagłówek.

I stało się, że po tych wydarzeniach Bóg (HaElohim) wystawił Abrahama na próbę (Rdz 22,1).

Po jakich wydarzeniach, dlaczego właśnie po nich i po co w ogóle próba? Podsumowujący sens pierwszej frazy sugeruje, że ów epizod nie mógł wydarzyć się wcześniej. Swoim kształtem przypomina prawie identyczną formułę

8 Jest to rodzaj doświadczenia, które pozostaje, nie przemija, gdyż jest ono absolutnie „jednostkowe”, i z tego względu można je przeżyć tylko raz. Po takim doświadczeniu chce się powiedzieć: nigdy więcej takich sytuacji. Owszem, trzeba ją było przejść, ale człowiek jest zdolny przeżyć takie zdarzenie raz jeden. Zdaje się, że Kant, a za nim współczesna wrażliwość, poprawnie odczytują jej wyjątkowość i graniczny charakter, mający coś z jednorazowości śmierci, widząc w tym doświadczeniu gorszący wymiar, bo wykraczający poza ludzką miarę. 
w Rdz 15,1, z którą tworzy tematyczną inkluzję, spajającą pewien całościowy segment historii Abrahama, osnuty wokół obietnicy syna (Rdz 15,4), która w Izaaku znalazła swoje wypełnienie ${ }^{9}$. Poprzedzająca wzmianka w Rdz 21,34, iż „Abraham przebywał w kraju Filistynów przez długi czas”, ma charakter krótkiego i lakonicznego streszczenia. Wskazuje ono na brak nowych i znaczących zdarzeń, dziejących się w tym okresie, które byłyby warte opowiedzenia. Ustanawia zatem czasowy dystans między wcześniejszymi zdarzeniami a tym, co ma nastąpić. Po narodzinach Izaaka i oddzieleniu go od Izmaela, w historii Abrahama nic nowego nie mogło się już stać. Dzieje boskiej obietnicy musiałyby się zakończyć na jego osobie, a on sam byłby jedynie ogniwem w biologicznym łańcuchu przekazywania życia. Potrzebna jest Boska interwencja, aby losy obietnicy mogły potoczyć się dalej. Sygnalizując brak nowych zdarzeń, te czasowe wzmianki usuwają przynajmniej częściowo arbitralność zapowiadanej próby. Z jednej strony bowiem sugerują, iż jego dotychczasowa historia doszła do swego kresu. Z drugiej zaś, podkreślają, że jej kulminacja w postaci spełnionej obietnicy syna jest problematyczna, ponieważ w jego fizycznej, ucieleśnionej postaci, oznacza swoistego rodzaju zamknięcie przyszłości. Jej otwarcie, bez wątpienia dramatyczne i przejmujące, inicjuje rozmowa Boga z Abrahamem, która uruchamia nowy i zaskakujący ciąg wypadków.

Oczywiście, sama zapowiedź próby stanowi wyraz przyjętej strategii retorycznej, adresowanej przede wszystkim do czytelników. Sytuuje ona analizowany epizod w specyficznym świecie biblijnych opowieści, których wyróżniającą cechą jest podstawowe założenie biblijnego monoteizmu, mianowicie wszechwiedza Boga ${ }^{10}$. W przypadku Rdz 22 reprezentuje ją narrator wszechwiedzący, który dzieli się nią z czytelnikiem, usuwając napięcie związane z następstwem zdarzeń i sytuując je $\mathrm{w}$ dialogach. Zamiast więc zareagować przerażeniem na polecenie złożenia ofiary z syna, czytelnik od samego początku wie, że będzie to tylko sprawdzian. Ale ta wiedza tylko pozornie czyni całe opowiadanie bar-

9 Lektura narracyjna stara się wyjaśnić zawiłości fabuły, jej przeskoki, znaczące niedomówienia oraz sieć intertekstualnych odniesień, z których jest utkana w ramach danego cyklu narracyjnego. Zbiór opowieści o Abrahamie rozpoczyna się w Rdz 12,1 i kończy się właśnie w Rdz 22,1-19, a wydarzenia opowiedziane w Rdz 23-25 mają jedynie charakter dopowiedzeń. Rdz 15 stanowi centrum fabularne tego cyklu, w którym wszystkie obietnice dane w Rdz 12-13 nie mają dla Abrahama większego znaczenia z powodu braku syna. I właśnie tutaj w Rdz 15,4 obietnica potomstwa otrzymuje swój konkretny, rozwiązujący jego sytuację kształt jako obietnica potomka. Jej losy, zmienne i zaskakujące, są treścią opowiadań w Rdz 16,1-18,15 oraz 21,1-21. Natomiast swój punkt kulminacyjny osiąga on w Rdz 22,1-19, por. L. A. Turner, Announcements of Plot in Genesis, JSOT Suppl. 96, Sheffield 1990, 87.

10 Zob. m.in. N. M. Sarna, Understanding Genesis, New York 1970, 162. 
dziej zrozumiałym i łatwiejszym do wyjaśnienia. Enigmatyczność pozostaje, gdyż nie ma podanego celu owej próby ani czego ona dotyczy. Tym samym, nagłówek za pomocą swoistych środków retorycznych nadaje kierunek lekturze: wiadomo, co się wydarzy, natomiast nie wiadomo, jaki jest sens owych zdarzeń, mających być próbą dla Abrahama. Na czym ona będzie polegać w warstwie dosłownej informuje pierwszy z dialogów, w którym Bóg znowu każe mu wyruszyć w drogę, lecz tym razem będzie to już jego ostatnia podróż.

Powiedział do niego: „Abrahamie”, a on odpowiedział: „Oto jestem”. Powiedział więc: „Weź twego syna, twego jedynego, którego kochasz, Izaaka, i udaj się do ziemi Moria, i tam złóż go w ofierze całopalnej na jednym ze wzgórz, o którym ci powiem" (Rdz 22,1-2).

Po raz pierwszy w Biblii ukazana jest rozmowa Boga z człowiekiem, w której zwraca się On do niego po imieniu, a ten odpowiada Mu krótką, także pierwszy raz użytą w takim kontekście formułą: hinneni - oto jestem. Bóg nie mógł ustanowić płaszczyzny dialogu z Adamem i jego żoną, bo oboje ukryli się przed Nim (por. Rdz 3,9). Także z Noem nie rozmawia, przekazując mu jedynie zapowiedź potopu i zawierając $\mathrm{z}$ nim przymierze. Nie podejmuje też rozmowy z Abrahamem, zwracając się doń z obietnicą lub oznajmiając mu swoje zamiary ( $\operatorname{Rdz} 18,16-33)$. Pierwsza taka możliwość zachodzi dopiero w tym epizodzie. Wzywając go po imieniu, bez następującego po nim polecenia, i oczekując na jego odpowiedź, Bóg ustanawia archetyp sytuacji dialogowej, obowiązującej nie tylko między Nim a człowiekiem, lecz także między ludzkimi osobami. Polega ona na stanięciu wobec siebie nawzajem w bezwarunkowej otwartości i gotowości do słuchania. Kluczowa tutaj partykuła hinneni pojawi się w naszym opowiadaniu jeszcze 2 razy, wprowadzając kolejne dialogi, mające decydujący wpływ na kierunek i rozwój fabuły. We wszystkich trzech miejscach ma ona postać skończonego zdania „oto jestem tutaj”"11, za pomocą którego Abraham staje przed swoim rozmówcą jako partner dialogu: „nie ruszam się stąd, nie ucieknę, choć nie wiem z jakim wezwaniem do mnie się zwrócisz, oto trwam w całkowitej gotowości, aby Cię wysłuchać". Objawia w ten sposób swoją pełną podmiotowość. Nie jest on już wyłącznie odbiorcą obietnic, a staje się tym, do którego Bóg zwraca się po imieniu i czeka na jego odpowiedź.

Dopiero w następstwie tej archetypicznej sytuacji dialogowej skierowany jest do niego Boży rozkaz „weź”, stonowany jednak partykułą grzecznością n’a $(\text { prosze })^{12}$, która zamienia go $\mathrm{w}$ łagodniejsze polecenie, bardziej pasujące do

11 Por. The Dictionary of Classical Hebrew, D. J. A. Clines (ed.), Vol. II, 578.

12 Por. The Dictionary of Classical Hebrew, D. J. A. Clines (ed.), Vol. V, 576. 
kontekstu dialogu i leżącej u jego podłoża relacji wzajemnego zaufania ${ }^{13}$. Dopełnienie czasownika „weź” składa się z sekwencji aż czterech elementów. Dla zrozumienia treści Bożego polecenia wystarczyłoby zapewne użycie imienia „Izaak”, które jednak pojawia się na samym końcu. Poprzedzają je natomiast określenia, które precyzują, kim on jest dla Abrahama i jaką pozycję zajmuje wewnątrz rodzinnych powiązań ${ }^{14}$.

Dodatkowo, trzykrotne użycie partykuły 'et przed każdym z określeń Izaaka oraz ich uszeregowanie zwraca uwagę na retoryczny wydźwięk polecenia Boga ${ }^{15}$. Jako nota accusativi pozostaje ona, co prawda, niewidoczna w polskich przekładach, ale w hebrajskim oryginale aż nadto rzuca się w oczy. Postać Izaaka zostaje ukazana w łańcuchu czterech, przesadnie pod względem gramatycznym zaakcentowanych dopełnień. Owo całkowicie zbędne mnożenie form, służących zidentyfikowaniu Izaaka jako jedynego przedmiotu miłości Abrahama nie jest pozbawione nuty subtelnej ironii. Słychać ją szczególnie tam, gdzie wybór i forma określeń, przedstawia go w wyłącznej relacji do Abrahama, z pominięciem jakichkolwiek odniesień do Sary oraz do samego Boga. A przecież dla Sary, bezpłodnej i starej, gdy go rodziła, Izaak musiał być bardziej jedynym synem niż dla Abrahama, mającego jeszcze Izmaela. Jak mocna była to więź świadczy wzmianka w Rdz 24,67, według której dopiero w związku małżeńskim z Rebeką znalazł on pociechę po śmierci matki. Podobnie, nie pojawia się tutaj nawet najmniejsza sugestia, że Izaak jest darem Boga, spełnieniem Jego obietnicy. To tak jakby Bóg chciał powiedzieć do Abrahama: to twój syn, choć otrzymałeś go ode Mnie jako mój dar dla ciebie, ale zagarnąłeś go dla siebie i uczyniłeś swoją wyłączną własnością. Z Boskiego daru, ustanawiającego więź wiary między Tym, kto obiecuje, a jego odbiorcą (por. Rdz 15,4-6), Izaak jako fizyczne ucieleśnienie obietnicy znajduje się teraz w całkowitym władaniu Abrahama ${ }^{16}$. Czyż to gramatyczne zaakcentowanie jego osoby jako przedmiotu posiadania nie sugeruje także, iż w świecie Abrahama, w którym jest on jego synem, i to jego jedynym, nie ma on statusu kogoś o własnej, odrębnej podmiotowości. Aż dotąd Izaak nie występuje jako samodzielny podmiot, zdolny do mówienia lub działania, nie pojawia się też jako główny bohater własnej, nieza-

13 Por. C. Westermann, Genesis 12-36. A Commentary, London 1986, 356.

14 H. C. White, Narration and Dicourse in the Book of Genesis, Cambridge 1991, 190.

15 Uszeregowanie dopełnień czasownika „weź”, bardziej naturalne od strony literackiej, mogłoby za Rdz 12,5 wyglądać następująco: „weź Izaaka, twego syna, jedynego, którego kochasz, i...”. Jakkolwiek, jest to drobna zmiana, ale odsunięcie imienia na koniec brzmi nieco sztucznie, przez co stanowi wyraźny sygnał retoryczny.

16 Por. H. C. White, Narration and Dicourse in the Book of Genesis, Cambridge 1991, 190. 
leżnej historii, należy raczej niepodzielnie do historii swego ojca. Ten brak podmiotowości sprawia, że także Bóg nie może się doń bezpośrednio i osobiście zwrócić. Dlatego mówiąc: „weź twego syna, twego jedynego, którego kochasz, Izaaka", zdaje się On akcentować właśnie owe sufiksy dzierżawcze, które określają go jako przedmiot ojcowskiego posiadania. Szczególnie ważną sprawą jest rozpoznanie ironicznego tonu w zwrocie: „którego kochasz”. Uczucia bowiem, szczególnie w relacjach rodzinnych mają tendencje do popadania w nadmierny patos, wypaczający tożsamość powiązanych ze sobą osób. Bóg zatem w zabarwionych delikatną ironią określeniach, odnoszących się do Izaaka, wprowadza emocjonalny dystans do niego, a przez to problematyzuje miłość Abrahama do syna. Dzięki temu nakaz złożenia go w całopalnej ofierze nie jest już tak przerażająco nieludzki. Czy Abraham nie rozpoznał owego ironicznego dystansu w głosie Boga, skoro nie wyraził swego protestu, jak wcześniej wobec żądania Sary, domagającej się odesłania Izmaela (Rdz 21,10-11)? ${ }^{17}$ Czy nie znalazł w nim także argumentu uzasadniającego swoje posłuszeństwo poleceniu Boga pomimo jego strasznie brzmiącej treści?

Izaak bowiem powinien pozostać synem obietnicy, gdyż w Rdz 15,4 od Boga właśnie Abraham otrzymał zapowiedź narodzin potomka, który po nim będzie dziedziczył. I wbrew swej bezdzietności, tym boleśniejszej, że był już w podeszłym wieku, uwierzył Bogu, że da mu syna. Czy spełniona obietnica może stać się własnością odbiorcy, który, stając się jej wyłącznym dysponentem w jej ucieleśnionej, fizycznej postaci, a nie w Dawcy obietnicy, będzie szukał zabezpieczenia swej przyszłości i pokładał w niej całą swoją nadzieję? Żeby tak się nie stało, Bóg każe mu złożyć tego jedynego i umiłowanego syna w całopalnej ofierze. Dlaczego ma to być aż całopalenie? Bo składana ofiara w całości musi być oddana Bogu i nic z niej nie może pozostać dla człowieka: ani dla ofiarodawcy, ani dla kapłana, który w jego imieniu ją ofiarowuje ${ }^{18}$. Użycie terminu ólah (ofiara całopalna) skłania do odczytywania całego wydarzenia poza porządkiem moralnym, widocznym w dosłownej warstwie epizodu, i szukania jego ukrytej wykładni wewnątrz symbolicznego świata kultu, gdyż rytualny akt jakim jest składanie ofiary, zawsze odsyła poza siebie, poza materialną dosłowność ofiarowywanego zwierzęcia, w obszar duchowych znaczeń. W tym sensie próba Abrahama wbrew Kantowi nie przeciwstawia się maksymie moralnej, gdyż należy ją umieścić bardziej w laboratorium wyobraźni wiary niż w sferze praktycznej. Nie oznacza też, jak chciał Kierkegaard, zawieszenia etyki w służ-

17 Por. L. A. Turner, Genesis, Sheffield 2000, 98.

18 Zob. J. Watts, Olah: The Rhetoric of Burnt Offerings, „Vetus Testamentum”, LVI, 1 (2006) 132. 
bie wiary, ponieważ celem próby jest przywrócenie podmiotowości Izaaka, która etykę dopiero umożliwia.

Można podejrzewać, że ten ukryty, duchowy sens znalazł odbicie również w postawie Abrahama. Bóg bowiem nie każe mu ofiarować syna tu i teraz, na oczach wszystkich, co może uczyniłoby go religijnym bohaterem, gotowym poświęcić swemu bóstwu to, co ma najcenniejsze ${ }^{19}$. Przeciwnie, doświadczenie, które ma przejść, będzie odbywać się z dala od spojrzeń potencjalnych widzów, w absolutnej samotności rozmowy prowadzonej w drodze między nim i jego synem oraz w skrytości ołtarza zbudowanego na górze, niedostępnego dla ewentualnych naśladowców, konstytuującego zarazem inną płaszczyznę dialogu - między nim a Bogiem.

$\mathrm{Z}$ tego względu druga część polecenia, rozpoczyna się od wezwania: lech-lecha (idź). Jest ono identyczne z formułą występującą w Rdz 12,1, inicjującą historię Abrahama. Razem tworzą klamrę spinającą jego losy w jedną całość. Przy czym, w pierwszym przypadku rozkaz dotyczy udania się do ziemi, którą Bóg mu pokaże, $\mathrm{w}$ drugim zaś chodzi o jeden z pagórków w krainie Moria, o którym On mu powie. To kolejna zmiana, skupiająca uwagę na dialogach. Zamiast natychmiastowego aktu złożenia ofiary Boskie polecenie zakreśla horyzont otwartej przyszłości. Jeśli Bóg nie żąda, żeby już tu i teraz złożyć syna $\mathrm{w}$ ofierze, a więc dokonać zamkniętego w sobie, niemoralnego aktu dzieciobójstwa, lecz każe mu iść w jakieś oddalone miejsce, to dopuszcza do głosu nadzieję w to, co niemożliwe ${ }^{20}$. Ustanowiony tutaj dystans przestrzenny i czasowy zmienia wymowę Boskiego polecenia. Abraham musi przecież pamiętać zatrważające a zarazem przepojone nadzieją pytanie gości, którzy wcześniej odwiedzili go pod dębami Mamre, zapowiadające narodziny Izaaka: „Czy jest coś niemożliwego dla Boga”. Izaak jako syn obietnicy rodzi się więc dwa razy: pomiędzy owymi dwoma niemożliwościami.

Abraham zatem będzie musiał nasłuchiwać głosu Boga i tylko na tym głosie polegać. Dlatego formuła lech-lecha przywołuje początek jego historii. Wtedy Bóg kazał mu opuścić całą swoją przeszłość, a więc ziemię ojczystą, klan i rodzinę, gdzie żył bezpiecznie pod opieką swego ojca Teracha (por. Rdz 11,27-32). Ale wyruszał wówczas do nieznanego kraju, mając przynajmniej Boskie obiet-

19 Por. publiczny charakter ofiary Jeftego w Sdz 11,30-40, zwłaszcza zaś króla Moabu, który na murach oblężonego miasta złożył ofiarę całopalną ze swego pierworodnego syna (2 Krl 3,27).

20 Podobnie L. A. Turner (Genesis, Sheffield 2000, 98-99). Odwołuje się on do wcześniejszego epizodu z odesłaniem Izmaela, który mimo to został przez Boga ocalony. Także w przypadku Izaaka Abraham może podobnie myśleć, o czym świadczą jego zdaniem enigmatyczne słowa patriarchy skierowane najpierw do sług, że obydwaj, on i syn powrócą do nich, oraz potem do Izaaka, że sam Bóg wybierze sobie baranka na ofiarę. 
nice ${ }^{21}$. Teraz, na końcu, kiedy to Izaak stał się jedyną jego rodziną i ziemią ojczystą ${ }^{22}$, został on ponownie wezwany, aby wyruszyć w drogę, na której będzie musiał stracić tego, w którym odnalazł swoją jedyną bezpieczną przyszłość. I to ostatnie wezwanie, otwierając jedynie wąską szczelinę nadziei, okazało się nieporównywalnie trudniejsze niż pierwsze.

Abraham wstał rano, osiodłał swego osła, wziął ze sobą dwóch swoich służących oraz Izaaka, swego syna, narąbał drzewa na ofiarę całopalną, i natychmiast wyruszył w kierunku miejsca, o którym powiedział mu Bóg (Rdz 22,3).

Na pierwszy plan tego opisu wybija się maksymalna oszczędność słów, lakoniczność sformułowań i reporterski, beznamiętny styl narratora, cechujący sprawozdanie $\mathrm{z}$ wykonania polecenia. Jego stawką jest pokazanie za pomocą powtórzeń lub ich braku, w jaki sposób Abraham je wypełni, w czym znajdzie odzwierciedlenie jego stosunek do Boga. Czy wyrazi swój sprzeciw, jak w przypadku odesłania Izmaela ( $\operatorname{Rdz} 21,9-12$ ) lub będzie negocjował, jak w kwestii zniszczenia Sodomy i Gomory (Rdz 18,16-32)? Czy w doświadczeniu, któremu został poddany, będzie antycypował postępowanie Hioba? Ta ostatnia analogia, choć prolog w Hi 1-2 może sugerować pewne podobieństwo, wydaje się chybiona. Hiob bowiem, choć w swoich początkowych reakcjach ukazuje się jako całkowicie pogodzony z nieszczęściem, to jednak później gwałtownie protestuje i jego protest jest niezmiernie wymowny. Abraham przeciwnie nie protestuje, nie buntuje się, milczy. Nie odzywa się ani jednym słowem. Wszystkie jego wewnętrzne motywy, myśli i uczucia, trzeba odczytywać, patrząc na jego zewnętrzne zachowania ${ }^{23}$. I narrator stara się je pokazać w sekwencji kilku starannie opisanych czynności.

Najpierw przygotowanie do podróży, obejmujące osiodłanie osła ${ }^{24}$, a następnie zabranie ze sobą dwóch służących i Izaaka oraz drewna, które wskazuje na zamiar złożenia ofiary całopalnej ${ }^{25}$. W tych dokładnie wyliczonych działaniach można się dopatrzyć jego decyzji zabicia syna. Przez nią daje

21 Por. L. A. Turner, Genesis, Sheffield 2000, 97.

22 Izmael z Hagar został odesłany, a Abraham nie ma jeszcze nawet skrawka ziemi Kanaan na własność (por. Rdz 23, gdzie dopiero po śmierci Sary nabędzie pole z pieczarą, w której pochowa swoją zmarłą żonę).

23 H. C. White, Narration and Dicourse in the Book of Genesis, 191-192.

24 Na dłuższą drogę zabierano ze sobą osła lub oślicę (por. $1 \mathrm{Krl} 2,40$ ) oraz służących, jak na to wskazuje paralelny epizod w $2 \mathrm{Krl}$ 4,22-24, przedstawiający Szunemitkę, wyruszającą do Elizeusza, aby prosić go za swoim zmarłym synem.

25 Obecność sług (n $n^{e e}$ arim) może sugerować, iż Abraham mógł przewidywać także jakąś ich rolę w złożeniu całopalnej ofiary, gdyż w podobnej funkcji występują młodzieńcy 
wyraz swemu doskonałemu posłuszeństwu Bogu' ${ }^{26}$. Tymczasem zostaje ono w jakimś stopniu zawieszone przez ostatnią część sprawozdania, która przywołuje Boskie słowo, rozkazujące mu udać się do miejsca, o którym On mu powiedziat. Otwierająca się tutaj perspektywa drogi powoduje odroczenie aktu ofiarnego, który będzie mógł być wykonany dopiero po przybyciu na wyznaczone miejsce. Czas ma tu kluczowe znaczenie. Istotnie, opowiadanie jest skomponowane według strategii szeregu czasowych odroczeń: służą jej zarówno dialogi jak i kolejność Abrahamowych czynności. Odłożenie na koniec przygotowania drewna na całopalenie odzwierciedla wewnętrzne napięcie, które odtąd będzie mu towarzyszyć aż do samego końca. Z jednej strony bowiem, wymaganie Boga jawi się przed nim jako nieuchronna, zewnętrzna konieczność, wynikająca z Jego obietnic, na których zawisło całego jego życie. Odmawiając wypełnienia Bożego nakazu (jak chciałby Kant), Abraham, musiałby zaprzeczyć swojej dotychczasowej historii, a więc wyprzeć się swojej tożsamości. Z drugiej zaś strony, czasowe odroczenie aktu ofiarnego budzi w nim nadzieję w ocalenie Izaaka, a więc w to, co jego posłuszeństwo właśnie czyni niemożliwym, a co może przyjść wyłącznie od strony Boga. Posłuszeństwo wbrew nadziei i nadzieja w to, co niemożliwe konstytuują dlatego paradoksalny charakter jego wiary.

Wskazuje on jeszcze na jeden, niezmiernie istotny rys jego sytuacji, spowodowanej posłuszeństwem Boskiemu nakazowi. Jego treść nie zawierała żadnych dodatkowych instrukcji, dotyczących sposobu i okoliczności złożenia ofiary. Podjęte czynności zdają się tworzyć kompletną listę, zrozumiałą jednak tylko dla niego samego i dla czytelników. Brakuje bowiem najważniejszej pozycji - zwierzęcia ofiarnego ${ }^{27}$. Jego nieobecność musi szczególnie rzucać się w oczy zewnętrznym obserwatorom, jakimi są Izaak i słudzy. Abraham zaś nie wyjaśnia im, po co wybierają się w drogę. Zresztą, jak mógłby to uczynić? Ten sam rodzaj niedomówień określa jego relację do Sary, która wiedząc o tym, prawdopodobnie usiłowałaby wpłynąć na zmianę jego decyzji, tak jak wcześniej zrobiła to w sprawie Hagar i Izmaela. Bez wątpienia wszyscy domyślają się, że nie może to być zwyczajna podróż, że wyruszają po to, aby złożyć ofiarę, a drewno będzie potrzebne do jej spalenia.

Wypełniając Boskie polecenie, Abraham skazuje się na milczenie, gdyż wkracza w doświadczenie, które ze swej natury jest nieprzekazywalne, a przez

(n ${ }^{\mathrm{e}}$ arim) w Wj 24,5, gdzie na polecenie Mojżesza składają całopalenia i ofiary wspólnotowe, por. H. F. Fuhs, na ar, TDOT IX, 483.

26 Tak rozumie postawę Abrahama Kierkegaard, definiując ją w kategoriach aktu wiary, teleologicznie zawieszającego zasady etyki (Bojaźń i drżenie, Warszawa 1969, 66nn.).

27 H. C. White, Narration and Dicourse in the Book of Genesis, 192. 
to sytuuje go w stanie całkowitego osamotnienia. Jedynym punktem odniesienia pozostaje więź z Tym, który do niego mówi. Nadaje ona jego postawie wiary znamię na wskroś osobistej i jednostkowej relacji, definiującej jego tożsamość nie tylko przed Bogiem, ale także wobec ludzi. Znajduje ona swoje odzwierciedlenie w kolejnej scenie, która otwiera się przed nim w chwili, gdy w oddali zarysowuje się kres ich wędrówki.

Trzeciego dnia podniósł Abraham oczy i dostrzegł miejsce z daleka. Wtedy powiedział do swoich sług: „Zostańcie tu z osłem, ja zaś i chłopiec pójdziemy tam, oddamy pokłon i wrócimy do was". Wziął zatem Abraham drwa na całopalenie i włożył na Izaaka, swego syna. Wziął też do ręki ogień i nóż, i wyruszyli obydwaj razem $(\operatorname{Rdz} 22,4-6)$.

Wraz z przybyciem na wyznaczone miejsce nadszedł dla Abrahama moment ostatecznych rozstrzygnięćc ${ }^{28}$. Przygotowania do podróży w Rdz 22,3 nosiły znamiona zewnętrznych i materialnych czynności. Natomiast trwająca trzy dni ${ }^{29}$ wędrówka odbywała się bardziej w przestrzeni duchowej niż fizycznej. Wewnątrz niej Abraham dojrzewał do wypełnienia Bożego nakazu ${ }^{30}$.

Nowy etap fabuły zaznaczony jest zmianą pozycji narratora, który w jakimś stopniu wymazuje siebie jako obserwatora zewnętrznego, przyjmując punkt widzenia głównego bohatera. Od tej chwili wydarzenia będą relacjonowane z perspektywy tego, co widzi Abraham. Kiedy podnosi oczy i dostrzega z oddali cel swojej podróży, dokonuje się w nim swoistego rodzaju rozpoznanie - anagnorisis $^{31}$. Oczywiście, nie jest to jeszcze moment przełomowy fabuły, a więc perypetia - przemiana losu, ta bowiem nastąpi dopiero przy drugim rozpoznaniu, pod koniec epizodu. Natomiast tutaj chodzi raczej o zwrócenie uwagi na to, co będzie się działo z osobą Abrahama, z jego postrzeganiem siebie i innych. To zaś oznacza przesunięcie akcji dramatycznej z zewnętrznych okoliczności na płaszczyznę wewnętrznych przeżyć głównego bohatera. Przy czym formuła „z daleka” sugeruje, iż jest to rozpoznanie niepełne, mgliste, wyrażające niepewność co do dalszego rozwoju zdarzeń.

Tym niemniej, w jego wyniku Abraham musiał podjąć jakieś postanowienia, gdyż przerywa milczenie i wyjaśnia swoje zamiary. Jego słowa zapowiadają nie tylko to, co zamierza zrobić. Wyrażają też ewolucję, jaka w nim zaszła pod

28 Por. C. Westermann, Genesis 12-36, 358-359.

29 Trzy dni nie rejestruje upływu czasu kalendarzowego, lecz okres poprzedzający szczególnie ważne wydarzenie, por. Rdz 31,22; 34,25; 40,20; Wj 3,18; 5,3; 19,11, tamże.

30 Por. H. C. White, Narration and Dicourse in the Book of Genesis, 192.

31 Wyróżniony przez Arystotelesa punkt fabuły, por. tenże, Poetyka, 1452a12-17. 
wpływem trzydniowej wędrówki. W pierwszym rzędzie zwraca się do sług, którzy reprezentują jego dom ${ }^{32}$. Wydając im polecenie pozostania $\mathrm{z}$ osłem u stóp góry, Abraham oddziela siebie i Izaaka zarówno od nich samych ${ }^{33}$ jak i od całego swego domu, a więc i od Sary. To pierwsze oddzielenie - od swego domu, toruje drogę do jednostkowego wymiaru wiary: wypełnienie tego, czego żąda od niego Bóg może się odbyć jedynie w Jego obecności, w ukryciu przed jakimkolwiek spojrzeniem ${ }^{34}$.

Rozpoczęty tutaj proces separacji idzie wszelako dalej. W Rdz 22,3 Abraham był jedynym podmiotem wszystkich czynności, podczas gdy słudzy, a także Izaak, zostali zredukowani do roli przedmiotów na równi z osłem i drewnem. W Rdz 22,5 pojawia się formuła: „ja i chłopiec”, w której teraz oddziela on siebie od Izaaka. Przyznaje mu w ten sposób nie tylko odrębną podmiotowość, ale określając go mianem „chłopiec”, zdobywa się wobec niego na emocjonalny dystans. To przesunięcie w sferze ojcowskich uczuć znamionuje pierwszy krok w kierunku oddania go Bogu. Zarazem jednak nie traci nadziei, że zostanie on w jakiś cudowny sposób ocalony. Dlatego oznajmia sługom, że po oddaniu pokłonu, wrócą obydwaj do nich. Gdyby bowiem powiedział, że powróci sam, zarówno Izaak jak i słudzy zaczęliby się domyślać, kto będzie zwierzęciem ofiarnym. A tego Abraham jeszcze nie wie. Wie tylko, że ma swego syna złożyć w całopalnej ofierze.

Przedłożone wyjaśnienie, owszem uspokaja Izaaka, ale też wzbudza w nim ciekawość odnośnie tego, co dalej ma się wydarzyć, zwłaszcza gdy obserwuje on przygotowania Abrahama do ostatniego etapu podróży. Nie mogła ujść jego uwadze kolejność poszczególnych czynności. Najpierw drewno na całopalenie wkłada na swego syna, potem bierze do ręki ogień, a na końcu nóż, potrzebny do zabicia ofiary. Czasowe odroczenie tej ostatniej czynności zdradza jego intencje: tutaj również postępuje w nadziei wbrew nadziei. A wtedy Izaak rozpoczyna rozmowę, która stanowi klucz dla zrozumienia całego opowiadania.

Powiedział więc Izaak do Abrahama, swego ojca i rzekł: „ojcze mój”. A on odpowiedział: „oto jestem, synu mój”. Tamten rzekł: „oto ogień i drwa, a gdzie baranek

32 Tutaj dopiero znajduje wyjaśnienie obecność sług i ich rola w strukturze fabuły, tak C. Westermann, Genesis 12-36, 359.

33 Nie jest wykluczone, że Abraham na początku przewidział dla swoich sług podobną rolę, jaką Mojżesz wyznaczył młodzieńcom w Wj 24,5. Kontekstem obydwu epizodów jest bowiem złożenie ofiary całopalnej. Z tego względu znaczenie owego pierwszego rozpoznania jest tym większe, że spoglądając w kierunku miejsca, wyznaczonego przez Boga, zmienia on zdanie, wyruszając tam samotnie, jedynie ze swoim synem.

34 Por. C. Westermann, Genesis 12-36, 359. 
na całopalenie?” Abraham zaś odpowiedział: „Bóg (Elohim) upatrzy sobie baranka na całopalenie, mój synu”. I szli obydwaj razem ( $R d z 22,7-8)$.

Dla Izaaka, czynności ojca wskazujące na zamiar złożenia ofiary przy jednoczesnej nieobecności zwierzęcia ofiarnego, musiały być szczególnie zagadkowe i wzbudzające ciekawość. Narrator jednak nie spieszy się ani ze sformułowaniem pytania przez Izaaka ani z udzieleniem jakiejś odpowiedzi przez Abrahama. Raczej w prostych i lakonicznych frazach celebruje samo wydarzenie rozmowy syna $\mathrm{z}$ ojcem. Eksponuje przy tym inicjatywę Izaaka, który nigdy dotąd nie występował w takiej roli, będąc zawsze biernym i niemym przedmiotem mów i działań innych. Tutaj zaś, po raz pierwszy pojawia się jako podmiot mówiący, zdolny do przemawiania własnym głosem, a niosąc drewno na całopalenie, także jako podmiot działajacy. Bez wątpienia, te dwa rodzaje uzdolnień, konstytuujące jego własną podmiotowość, okazały się możliwością stworzoną dopiero przez naturę Boskiego polecenia, które z jednej strony skazuje Abrahama na milczenie, z drugiej zaś każe mu wykonywać czynności, domagające się wyjaśnienia ze względu na ich zagadkowy przebieg.

Retoryczny układ tej rozmowy jest uderzająco podobny do pozostałych dialogów zainicjowanych przez Boga. Przez dwukrotne użycie czasownika wajjomer (powiedział... i rzekł) narrator zwraca uwagę na pierwszoplanową rolę Izaaka jako tego, w którego słowach odbija się echem Boski głos. jako podmiotu mówiącego. Co więcej, zadane przezeń pytanie i otrzymana nań odpowiedź definiują w sposób rozstrzygający jego tożsamość.

Najpierw jednak rozmówcy odnoszą się do siebie za pomocą określeń, które precyzują ich wzajemne relacje, ustalając płaszczyznę toczącego się między nimi dialogu. Ta wymiana odbywa się podczas drogi, w perspektywie zbliżającego się nieuchronnie aktu ofiarnego, w którym rodzinne więzy Izaaka, a więc synowskie z Sarą i dziedzica z całym domem, ulegną definitywnemu zerwaniu. Poza odniesieniem do Abrahama, zawartym w słowach „ojcze mój” Izaak nie posiada żadnego innego punktu zaczepienia, na którym mógłby się oprzeć. Dlatego cała jego egzystencja zawiera się w owym „ojcze mój”, sprawiając, że ofiara zeń złożona będzie doskonałym, w całości oddanym Bogu całopaleniem. Wiedzą o tym dobrze zarówno czytelnicy jak i sam Abraham, który na to bezwarunkowe oddanie się syna odpowiada formułą „oto jestem”. Powtarza więc słowa, które na początku wypowiedział wobec wzywającego go Boga. I podobnie jak wtedy, tak również teraz wyrażają one analogiczną gotowość do bezwarunkowego słuchania. Ojciec staje wobec syna, aby go słuchać, tak słuchać, jak samego Boga. Zazwyczaj to synowie a nie ojcowie mają być gotowi do słuchania. Jest jednak jeden wyjątek, mianowicie, kiedy syn zadaje pytanie, a jego stawką są jego losy, cała jego przyszłość. Abraham wie, że Izaak nie 
będzie się pytał o to, co istnieje wokół nich, wiedziony pragnieniem poznania świata. Wszystko to zostaje zawieszone, gdyż w drodze na górę Moria waży się to, kim jest. Dodając więc zwrot „synu mój”, nie tylko nakierowuje swoje ojcowskie słuchanie na jego osobę, ale zobowiązuje się także do udzielenia mu prawdziwej odpowiedzi, która pomoże mu odnaleźć swoją tożsamość. Dopełnia się w ten sposób separacja syna od ojca, fundująca jego odrębną i niezależną podmiotowość. Gdyby Izaak nie zadał swego pytania pozostałby biernym przedmiotem ślepego posłuszeństwa Abrahama, czyniąc go zwykłym dzieciobójcą i uniemożliwiając mu pomyślne przejście próby.

Od strony formalnej pytanie Izaaka w strukturze analizowanego epizodu odzwierciedla podobne sytuacje opisane w Wj 12,26-27; 13,11-17; Pwt 6,20-25. Definiują one warunki, na których odbywa się przekaz wiary - traditio. U jego podstaw leży pytanie synów, skierowane do ojców, o znaczenie rytuałów, praw i nakazów, zleconych przez Boga. Analogiczną funkcję zdaje się pełnić rozmowa Izaaka z Abrahamem. Ojcowskie przygotowania do złożenia ofiary całopalnej przy jednoczesnej nieobecności zwierzęcia ofiarnego musiały być dlań wystarczająco zagadkowe, aby wzbudzić w nim ciekawość co do ich znaczenia. Dlatego pyta on swego ojca: „oto ogień i drwa, a gdzie baranek na całopalenie?". Dramatyczność tego pytania i wzrastające napięcie w powstałej sytuacji odzwierciedla pominięcie noża, przecież niezbędnego w rytuale ofiarniczym. Czyżby Abraham ukrył go przed spojrzeniem swego syna, wskazując tym samym na toczącą się w nim wewnętrzną walkę? Jej istotę stanowi konfrontacja dwóch koncepcji religii: jednej, wyrażającej się w materialnej dosłowności, drugiej, znajdującej swój wyraz w sferze symbolicznej. Przejście od jednej do drugiej dokonuje się w Abrahamowej odpowiedzi: „Bóg upatrzy sobie ofiarę na całopalenie, synu mój”.

Nie informuje on tutaj Izaaka co dalej ma nastąpić, nie przekazuje mu też religijnej wiedzy. Raczej odsyła on swego syna do Boga, każąc mu od Niego oczekiwać odpowiedzi ${ }^{35}$. Charakter tego odesłania jest na wskroś egzystencjalny. Izaak bowiem musi zacząć wierzyć (albo nie) tak jak Abraham lub nawet mocniej, wierzyć przez całą dalszą drogę aż do ostatniego momentu, w którym to sam Bóg wskaże wybraną przez siebie ofiarę całopalną ${ }^{36}$. Izaak nie jest już bezbronną i nieświadomą swego losu ofiarą dzieciobójczych zamiarów swego ojca. Jako czytelnicy przestajemy litować się nad nim, wyobrażając sobie jego przerażone oczy i widoczny w nich strach przed śmiercią z ręki Abrahama.

35 Por. H. C. White, Narration and Dicourse in the Book of Genesis, 194.

36 Doskonale to wychwyciła żydowska tradycja targumiczna, rozwijająca ten motyw w bardziej aktywną rolę Izaaka, polecając mu prosić Abrahama, aby związał go mocno po to, by jego ofiara Bogu była doskonała. 
Przeciwnie, zaczynamy dostrzegać jego własne zmaganie wiary, podobne do tego, które odbywa się w jego ojcu, zmaganie, które czyni go podmiotem wierzacym, niezależnym od wiary innych, lecz ufundowanym na odrębnej relacji do Boga. Na tym właśnie polega przekaz wiary. Abraham wypuszcza ze swoich rąk, ze swojej ojcowskiej władzy swego syna, całe jego życie, z całą jego przeszłością i przyszłością, i oddaje Bogu. W ten sposób Izaak może stać się bezpośrednim adresatem mowy Boga (Por. Rdz 26,2-5), który do tej pory przemawiał wyłącznie do Abrahama. Stawką tej krótkiej wymiany między synem a ojcem jest przyszłość Boskiej obietnicy. Nie da się jej przekazać środkami czysto ludzkimi, na przykład informując o niej. Chodzi tu o to, jak dziecko obietnicy ma się stać odbiorcą obietnicy, a więc znaleźć się w takiej sytuacji egzystencjalnej, w której samo będzie zdolne słuchać Boga ${ }^{37}$. Właśnie ta ojcowska odpowiedź Abrahama na pytanie syna umożliwia Izaakowi osobiste, bez pośrednictwa innych, zwrócenie się ku Bogu. Odtąd, obydwaj idą dalej razem, tak jak na początku rozmowy, ale teraz każdy z nich kroczy własną, oddzielną ścieżką wiary. Tym zatem, co jednoczy ich na tej drodze nie jest już tylko synowsko-ojcowskie przywiązanie, ale Bóg, na którym zawisło życie obydwu, i który wiąże ich losy wspólnym aktem ofiarnym.

Przybyli więc na miejsce, o którym powiedział mu Bóg (HaElohim). Abraham zbudował tam ołtarz, następnie ułożył drwa, wreszcie związał Izaaka, swego syna i położył go na ołtarzu, na drwach. I wyciągnął Abraham rękę, wziął nóż, aby zabić na ofiarę swego syna. Wtedy zawołał do niego anioł PANA (Malak JHWH) z nieba i powiedział: „Abrahamie, Abrahamie”. Ten zaś odpowiedział: „Oto jestem”. Wówczas powiedział: „Nie podnoś swej ręki na chłopca i nie czyń mu nic, ponieważ teraz wiem, że jesteś bojącym się Boga (Elohim) i nie odmówiłeś mi swego jedynego syna" (Rdz 22,9-12).

Początkowa wzmianka o przybyciu na miejsce nawiązuje do Rdz 22,2, zamykając klamrą wszystkie zaistniałe dotąd zdarzenia, i nakładając na nie sens wypełnienia: Abraham wykonał rozkaz Boga i znalazł się w miejscu, o którym mu powiedział. Jego zewnętrzne posłuszeństwo Boskiemu nakazowi i towarzyszące mu wewnętrzne przeświadczenie w ocalenie syna wbrew nadziei, osiągają tutaj swój najbardziej paradoksalny wymiar. Ta dwuznaczność w postawie Abrahama udziela się niewątpliwie także czytelnikom, którzy nie są pewni jak ostatecznie on się zachowa.

Zgodnie z oczekiwaniami, Abraham rozpoczyna od zbudowania ołtarza. Jednak następne czynności znacząco odbiegają od układu składania ofiary

37 Por. H. C. White, Narration and Dicourse in the Book of Genesis, 194-195. 
całopalnej, znajdującego odbicie w przepisach zawartych w Księdze Kapłańskiej $^{38}$. Te ostatnie bowiem nakazują najpierw zabić żertwę ofiarną, dzieląc ją na części, a dopiero później ułożyć je na drwach, leżących na ołtarzu, po uprzednim podłożeniu na nim ognia ${ }^{39}$. Abraham odsuwa zabicie Izaaka na sam koniec. Zamiast go zabić wiąże go, układając żywego na drwach, ale nie podkłada w ogóle ognia. To zbyt wiele odstępstw od norm jak na jeden rytuał $^{40}$. Tym bardziej uderzających, że wierność przepisom liturgicznym decydowała o przyjęciu ofiary przez Boga.

Te anomalie jednoznacznie wskazują na próby odroczenia zabicia Izaaka i świadczą o tym, że Abraham toczy wewnętrzną walkę między posłuszeństwem boskiemu nakazowi a wiarą $\mathrm{w}$ to, co niemożliwe, czyli ocalenie syna. Dodatkowym efektem tego zmagania jest wrażenie drastycznego spowolnienia czasu wykonywanych przez niego czynności. Pozwala ono także Izaakowi zaistnieć jako podmiot wiary. Po zbudowaniu ołtarza i ułożeniu na nim drzewa, Abraham skupia się na swoim synu. Wiąże go i kładzie żywego na drwach. Żadne przepisy kultyczne nie pozwalają umieścić na ołtarzu żywej żertwy ofiarnej ani też nie wspominają o jej uprzednim związaniu. Nawet więc, jeśli Izaak został związany, to powinien być zabity u stóp ołtarza i dopiero potem położony na drwach.

Obserwując te nieprawidłowości, musiał on dostrzec podwójną intencję w postępowaniu ojca. Abraham, nie zachowuje się jak religijny fanatyk, starając się co do litery wypełnić przepis. Związując swego syna, wyraża zamiar oddania go w ofierze Bogu, ale układając go żywego na ołtarzu, podtrzymuje w sobie nadzieję na jego uratowanie. Tym samym również Izaak może zacząć wierzyć, godząc się jednocześnie z ojcowskim posłuszeństwem Bogu, który aż do tej pory nie odezwał się ani słowem i nie dał żadnego znaku.

Dlatego Abraham wie, że musi doprowadzić do samego końca akt składania ofiary. Poprzedza go czynność związania Izaaka i ułożenia go na drwach, na ołtarzu. Termin „związanie”, występujący wyłącznie w tym jednym miejscu w całej Biblii, musi mieć własne znaczenie, wynikające $\mathrm{z}$ rozwoju fabuły. Ponieważ nie jest ono nigdzie zalecane w przepisach kultycznych, musi wyrażać intencję Abrahama, jego własny wkład w rytuał całopalenia. Związanie jako własne działanie Abrahama wobec Izaaka odzwierciedla zatem nieodłączny

38 Szczegółowe omówienie poszczególnych czynności rytuału całopalenia zawiera ks. A. Tronina, Księga Kapłańska, Nowy Komentarz Biblijny, Stary Testament, t. III, Częstochowa 2006, 72-79.

39 Por. na przykład kolejność kapłańskich czynności podczas składania ofiary całopalnej w Kpł 1.

40 Trafna obserwacja L. A. Turner, Genesis, 99. 
wymiar ojcostwa, wyrażający się w posiadaniu dziecka. Owe więzy ojcowskiej miłości okazują się jednak skrępowaniem podmiotowości Izaaka, uniemożliwiając mu rozpoczęcie samodzielnego, niezależnego życia. Sięgając więc po nóż, Abraham objawia swoją wolę oddania Bogu tego, który stał się jego całkowitą własnością. Doskonałość jego ofiary nie polega więc na wierności przepisom kultycznym, lecz znajduje odbicie w jego intencji.

Czas opisu tej ostatniej czynności jest $d \nmid u z ̇ s z y$ niż czas jej wykonania. Tutaj spowolnienie czasu, a wraz z nim i cała fabuła, osiągają swój punkt przełomowy (perypetię): Abraham najpierw wyciąga rękę, potem chwyta za nóż. Cała scena rozgrywa się przed oczyma czytelników jakby w zwolnionym tempie, skupiając ich spojrzenie na ręce Abrahama, której ruch odsłania jego zamiar złożenia $\mathrm{w}$ ofierze Izaaka ${ }^{41}$. Właśnie $\mathrm{w}$ tym momencie dopełnia się i udoskonala jego ofiara: oddaje Bogu swego syna w sposób ostateczny, całkowity i nieodwołany.

Na tę chwilę czekał anioł PANA (Malak JHWH), który niezwłocznie zwraca się do niego, dwa razy wymieniając jego imię: „Abrahamie, Abrahamie”. W tym podwójnym użyciu imienia daje się słyszeć przynaglający ton, który domaga się natychmiastowego przerwania rytuału, czym potwierdza fakt rozpoznania ze strony Boga kluczowego momentu próby ${ }^{42}$. Napięcie jej towarzyszące dochodzi tu do swego apogeum i ostatecznego rozwiązania. Odpowiadając „oto jestem”, Abraham zatrzymuje się w swoim działaniu i przyjmuje postawę absolutnej gotowości do słuchania ${ }^{43}$. Wzmacnia ją pewność, że anioł PANA, który się doń zwraca, przemawia $z$ nieba. Owo dopowiedzenie „z nieba” jest konieczne, aby Abraham był przekonany, iż głos HaElohim, nakazujący mu złożyć Izaaka w ofierze całopalnej i głos Malak JHWH, powstrzymujący jego rękę przed zabiciem syna, to głosy tego samego Boga. Nie przeciwstawiają się one sobie, lecz współbrzmią w jedności fabuły, znacząc zmiany jakie się dokonują w tożsamości ojca i syna, oraz w ich wzajemnych relacjach.

W Rdz 22,2 HaElohim poleca Abrahamowi: „weź swego jedynego syna, którego miłujesz, Izaaka”, a w Rdz 22,12 Malak JHWH mówi doń: „nie podnoś ręki na chłopca i nie czyń mu nic”. Przejście od pozycji syna do pozycji chłopca znamionuje zdystansowanie emocjonalne Abrahama w stosunku do Izaaka, osiągnięte w przerwanym rytuale złożenia go w ofierze całopalnej. Zarazem słowa „nie czyń mu nic” zabezpieczają Izaaka przed jakąkolwiek przyszłą inge-

41 Por. H. C. White, Narration and Dicourse in the Book of Genesis, 196.

42 Por. C. Westermann, Genesis 12-36, 361.

43 Zabrakło jej Saulowi, który nie czekając na przybycie proroka Samuela, sam pospiesznie złożył ofiarę. Okazała się ona jednak bez wartości: „Czyż bowiem PANU bardziej podobają się całopalenia i ofiary niż słuchanie głosu PANA? Otóż, lepsze jest posłuszeństwo od ofiary, nadstawianie uszu od tłuszczu baranów" (1 Sm 15,22). 
rencją ojca w jego życie, otwierając przed nim perspektywę osobistego odniesienia się do Boskiej obietnicy ${ }^{44}$. Odtąd będzie on mógł żyć na własną rękę pod znakiem Boskiego słowa, zaadresowanego bezpośrednio i osobiście do niego, co sprawi, że Bóg będzie nazywał siebie nie tylko Bogiem Abrahama, lecz także Bogiem Izaaka.

Dalej następuje wyjaśnienie próby: „teraz wiem, że jesteś bojącym się Boga i nie odmówiłeś mi swego jedynego syna”. Czym jest owo „wiem” w świetle biblijnego założenia wszechwiedzy Boga? Nie zaprzecza ono tej ostatniej, gdyż w strukturze fabuły ma ono status rozpoznania (anagnorisis), odsłaniającego sens dziejących się wydarzeń i potwierdzającego pomyślne przejście testu przez Abrahama. To on jest jego adresatem oraz potencjalni czytelnicy jego historii. Co więcej, jego celem jest zdefiniowanie zachowania patriarchy jako paradygmatycznej postawy bojacego się Boga i ukazanie w niej normatywnego wzorca prawdziwej pobożności.

Druga część wyjaśnienia przynosi odpowiedź na pytanie o sens Abrahamowej ofiary. Nie jest nią żądanie zabicia syna w ofierze całopalnej, lecz oddanie go Bogu, które dokonuje się w akcie ofiary duchowej, a nie materialnej. Ta zaś z kolei odzwierciedla fundamentalna zależność odbiorcy obietnicy od jej Dawcy w wymiarze czasowym. Losy Abrahama nie zamykają się w jej materialnym spełnieniu w postaci syna, lecz rozwijają się narracyjnie w kierunku otwartej przyszłości. Ta zaś przynosi zaskakujące rozwiązanie.

Wówczas Abraham podniósł swoje oczy i spostrzegł: a oto z tyłu baran zaplątany rogami w zaroślach. Abraham więc podszedł, wziął barana i złożył go w ofierze całopalnej zamiast swego syna. Abraham nadał nazwę temu miejscu „PAN (JHWH) widzi”. Stąd mówi się dzisiaj: „Na górze PAN (JHWH) się ukazuje” (Rdz 22,13-14).

Głos Boga, powstrzymujący rękę Abrahama przed zabiciem syna to przełomowy moment fabuły - perypetia, po której nie należałoby się spodziewać żadnych nowych wydarzeń, gdyż akcja dramatyczna i towarzyszące jej napięcie powinny szybko zmierzać ku swemu rozwiązaniu. Wbrew jednak oczekiwaniu czytelników na taki konwencjonalny przebieg ostatniego etapu opowieści, historia Abrahama ofiarującego swego syna przyjmuje nowy, zaskakujący zwrot. A dokonuje się on za sprawą drugiego rozpoznania (anagnorisis), realizującego się w podwójnym ruchu. Najpierw Abraham podnosi oczy, do tej pory skupione na swoim synu. A wtedy spostrzega barana, zaplątanego rogami w zaroślach.

44 Nie sprzeciwiają się temu starania Abrahama o sprowadzenie żony dla Izaaka, opisane w Rdz 24, gdyż jego instrukcje przekazane słudze pozostawiają szeroki margines dla działania Boga, wskazując, iż to ostatecznie On sam wybrał żonę dla Izaaka, por. szczególnie Rdz 24,42-44. 
Wszelako baran znajduje się $z$ tyłu, Abraham zatem musi nie tylko oderwać wzrok od syna, lecz także odwrócić się od niego. Uwięziony w zaroślach baran musiał znajdować się tam już od pewnego czasu, a jego zaplątanie nie mogło być zupełnie przypadkowe. Składając go zamiast syna w ofierze, Abraham odchodzi od przyjętego ceremoniału, przynajmniej w dwóch miejscach. Zwierzę ofiarne nie pochodzi z jego własnej trzody, a więc nie jest jego osobistym darem dla Boga, który także ze swej strony nie wydał mu bezpośrednio rozkazu ofiarowania go na całopalenie ${ }^{45}$.

Akt złożenia barana w ofierze musi być zatem własną inicjatywą Abrahama. Jak do niej doszło? Nie mogło się tutaj obyć bez jakiegoś wewnętrznego oświecenia, którego doznał na widok zwierzęcia schwytanego w zaroślach. To ono jest ofiarą, którą upatrzył sobie Bóg. Rytuał całopalenia jest przecież tylko na moment przerwany głosem $\mathrm{z}$ nieba. Jego logika domaga się, aby Abraham zinterpretował obecność barana jako możliwość jego dopełnienia. Tym niemniej, wynotowane powyżej odstępstwa ujawniają w nim znaczące pęknięcia. Pierwsza nieciągłość, czasowa, pomiędzy zamiarem zabicia syna a faktem złożenia w ofierze barana, otwiera miejsce na duchową ofiarę, wyrażoną w wewnętrznej intencji. $\mathrm{W}$ niej Abraham już złożył ofiarę duchową zanim złożył ofiarę materialną. Druga nieciągłość, przestrzenna, pomiędzy obecnością Izaaka na ołtarzu ofiarnym a przypadkową obecnością barana w zaroślach, wskazuje, że materialna ofiara jest całkowicie zewnętrzna i pusta, i sama w sobie pozbawiona znaczenia. Nie pochodząc $\mathrm{z}$ trzody Abrahama baran nie przedstawia żadnej wartości jako jego własny dar. Ponadto, brak szczegółowego opisu złożenia go w całopalnej ofierze powoduje, iż na zasadzie kontrastu jeszcze mocniej zostaje wyeksponowana wewnętrzna, duchowa ofiara Abrahama, wyrażająca się w intencji zabicia syna. To ona stanowi treść materialnej ofiary, która jako taka jest instytucją ludzką, nie boską. Dlatego Bóg w materialnym znaku zwierzęcia ofiarnego widzi duchową ofiarę człowieka, i w niej zawiera się cel wszystkich ludzkich ofiar.

W pytaniu syna o baranka ofiarnego, Abraham musiał więc słyszeć inne o to kim jest Izaak. Ostatecznie zaś wybrzmiewa w nim pytanie samego Boga o status ludzkiej osoby, która zawsze jest najpierw czyimś dzieckiem zanim stanie się sobą, kimś odrębnym, powołanym do zainaugurowania własnej, niezależnej historii życia. Jego przyszłe losy są treścią ostatniego dialogu Boga z Abrahamem.

Zawołał anioł PANA (Malak JHWH) drugi raz z nieba, i rzekł: „Przysięgam na samego siebie - wyrocznia PANA (JHWH) - ponieważ tak postąpiłeś i nie odmówiłeś mi swego jedynego syna, dlatego zapewniam ci moje błogosławieństwo: roz-

45 Dwie niezwykle trafne obserwacje, poczynione przez H. C. White, Narration and Dicourse in the Book of Genesis, 198. 
mnożę niezmiernie twoje potomstwo, jak gwiazdy na niebie i jak piasek na brzegu morza, a twoi potomkowie posiądą bramy swoich nieprzyjaciół. Wszystkie narody ziemi będą siebie błogosławić przez twoich potomków, ponieważ posłuchałeś mojego głosu”. Potem Abraham wrócił do swoich sług. Następnie udali się razem do Beer-Szeby. I Abraham zamieszkał w Beer-Szebie (Rdz 22,15-19).

$\mathrm{Z}$ punktu widzenia rozwoju fabuły, ta druga interwencja $\mathrm{z}$ nieba wydaje się zupełnie zbyteczna ${ }^{46}$. Złożenie bowiem $\mathrm{w}$ ofierze barana zamiast Izaaka rozwiązuje wszelkie napięcie związane $\mathrm{z}$ ofiarą tego ostatniego. Także treść obietnicy wzmocnionej przysięgą odbiega od sformułowań, użytych wcześniej i bardziej przypomina obietnicę daną Izaakowi w Rdz 26,2-547. Skoncentrowana na osobie Izaaka w dopiero co opowiedzianych wydarzeniach teraz przyjmuje ogólną formę zapowiedzi licznego potomstwa, która tchnie otwartą przyszłością i wybiega daleko w przód. Funkcjonuje zatem jako przejście do następnego etapu historii zbawienia, w którym samodzielnym podmiotem będzie już Izaak. Rzeczywiście, kiedy Abraham składa barana na całopalenie, Izaak znika z oczu. Ten, który od pierwszych słów Boga, polecającego złożyć go w ofierze, pozostawał przez cały czas w centrum uwagi i zainteresowania, zarówno Abrahama jak i czytelników, śledzących jego los, w drodze powrotnej patriarchy i jego sług jest wymownie nieobecny. Teraz to właśnie ta jego nieobecność jest intrygująca. Sugeruje ona, że puste miejsce, które po nim zostało stanowi ostateczne wyjaśnienie całej opowieści. Stąd szereg pytań, które stawia takie jej zakończenie.

Dlaczego Izaak nie wrócił razem $\mathrm{z}$ ojcem do sług, a potem z nimi do Beer-Szeby? Co się z nim działo, gdy Abraham składał zamiast niego ofiarę z barana? Czyż nie musiał wpierw go rozwiązać i pozwolić mu zejść z ołtarza, wyjaśniając mu przy tym sens dramatycznych wydarzeń, które obaj przeszli? Czy za odejściem Izaaka kryje się jakaś jego osobista decyzja, a w związku z tym, czy różni się ono od odesłania Izmaela? Bez wątpienia, obydwa epizody mają jakieś aspekty rytuałów inicjacji, wprowadzających w dorosłe życie. Przy czym jedynie w tym drugim przypadku odbywa się on w ramach traditio - przekazu wiary.

Wydaje się zatem, iż owo wzgórze w krainie Moria zostało wyznaczone przez Boga nie tyle dla złożenia na nim ofiary z syna, lecz jako miejsce rozstania ojca z synem, w wyniku którego Izaak będzie mógł rozpocząć własną, odrębną

46 Na poziomie kompozycji egzegeza historyczno-krytyczna rozpoznaje tutaj dodatek, który prawdopodobnie wyszedł z ręki autorów deuteronomistycznych, włączających opowiadania patriarchalne w szerszy kontekst, por. C. Westermann, Genesis 12-36, 363.

47 Por. H. C. White, Narration and Dicourse in the Book of Genesis, 200nn. 
historię życia. Czy to rozstanie mogło się dokonać w inny, mniej bolesny sposób? Prawdopodobnie nie. Ludzka miłość zawiera w sobie tak wielką skłonność do posiadania, a tym samym do przekształcania ukochanego w przedmiot, którego losy określone są przez prawo własności kochającego, że jedynie Boskie polecenie złożenia go w ofierze mogło to zmienić. Co więcej, również Izaak nie był zdolny sam odejść od swego ojca, żyjąc bezpiecznie pod jego opieką, dlatego w sferze symbolicznej także on składa ofiarę ze swej całkowitej zależności do ojca, oddając się Bogu. Potwierdzają to kalkulacje dotyczące wieku Izaaka $\mathrm{w}$ momencie składania go $\mathrm{w}$ ofierze. Zaraz bowiem po tym epizodzie umiera Sara, mając 127 lat, a urodziła go w wieku 90 lat ${ }^{48}$. Izaak ma zatem 37 lat, ale dla ojca, a zapewne też i dla matki ciągle był „chłopcem”, wymagającym rodzicielskiej opieki ${ }^{49}$. Gdyby nie wydarzenie na górze Moria nigdy by nie dorósł i nie rozpoczął dorosłego i samodzielnego życia pod znakiem obietnicy, skierowanej już do niego, a nie tylko do ojca.

Próba, przez którą obydwaj przeszli - ojciec i syn - nie była na próżno. Nie okazała się wyrazem boskiego kaprysu ani była przejawem szaleństwa Abrahama ${ }^{50}$. Chodziło w niej bowiem przede wszystkim o spowodowanie odejścia Izaaka i umożliwienie mu wejścia w dorosłe życie, ale jako nosiciela obietnicy, dzięki czemu także jego imię znajdzie się w określeniu Boga patriarchów jako Boga Izaaka. I musiała ona mieć właśnie taki przebieg jako polecenie złożenia go w ofierze całopalnej, aby rozstanie ojca z synem nie było połowiczne i nie mogło być cofnięte, aby Izaak mógł odzyskać całkowicie swoją podmiotowość i potrafił samodzielnie stanąć przed Bogiem. Stało się to możliwe w doświadczeniu, które zostało przekazane Izaakowi, a które posiada cechy postawy nazwanej w Rdz 15,6, terminem „uwierzyć”. Czasownik ten w kontekście losów Abrahama wiąże się z ryzykiem utraty wszystkiego i wyraża gotowość całkowitego zdania się na słowo Boskiej obietnicy.

Te obietnice stały się impulsem jego nowego życia, nadając mu jedyny i niepowtarzalny kształt. W przebiegu całego cyklu Abrahama zmieniają swoją postać: z ogólnych i wybiegających w daleką przyszłość powoli przechodzą

48 Por. H. Ch. Brichto, The Names of God, 280.

49 Podobne anomalie przedstawia epizod, opisujący odesłanie Izmaela. W chwili wydalenia Izmael miał przynajmniej 17 lat (por. Rdz 17,25: 13 lat; 18,10: plus rok; 21,8-10: plus 3 lata - wiek, w którym Izaak został odstawiony od piersi), a narrator każe Abrahamowi włożyć go na barki matki, jakby był małym dzieckiem, por. Rdz 21,14 (tak oryginał hebrajski). Ten rodzaj opisu pokazuje dysproporcję między obrazem dziecka jaki mają jego rodzice i stanem faktycznym, wynikającym z jego aktualnego wieku. Izaak nie potrafił nawet sam znaleźć sobie żony, o którą musiał dla niego postarać się Abraham, choć uczynił to nie bezpośrednio, lecz zdając się na Boskie prowadzenie, por. przypis 43 .

50 Por. H. Ch. Brichto, The Names of God, 279nn. 
w bardziej konkretne i w swej realizacji coraz bliższe czasowo. Wreszcie pojawia się specyficzna forma zapowiedzi syna, którego ma urodzić Sara. Wszystkie okoliczności towarzyszące spełnieniu tej obietnicy skłaniają go do przyjęcia Izaaka jako daru od Boga. Traktując jednak Izaaka jako materialne spełnienie obietnicy, Abraham całą swoją przyszłość uzależnił od osoby syna, czyniąc go swoją własnością i odrywając go od Boskiego Dawcy. Oznaczało to zamknięcie przyszłości na osobie Izaaka i uniemożliwienie kontynuacji historii zbawienia. Izaak miał pozostać po prostu synem Abrahama jako biologiczne ogniwo w naturalnym łańcuchu przekazywania życia. Stąd próba, podczas której, będąc posłusznym głosowi Boga, oddaje Mu na powrót otrzymanego odeń syna, aby i on mógł zainaugurować własną historię życia pod znakiem obietnicy, bezpośrednio doń zaadresowanej.

\section{Podsumowanie}

Opowiadanie o ofiarowaniu Izaaka na samym początku nazwane jest próbą, która ze względu na treść Boskiego polecenia, przyjmuje postać złożonej fabuły, z umiejętnie budowanym napięciem i kilkoma nagłymi, nieoczekiwanymi zwrotami akcji. Jej punkt kulminacyjny przyjmuje postać rytuału składania ofiary całopalnej, lecz w postępowaniu Abrahama widoczne są znaczące odstępstwa od porządku czynności, ustalonych w przepisach kultycznych. Sugerują one, iż fabuła rozgrywa się $\mathrm{w}$ istocie na dwóch planach: posłuszeństwa głosowi Boga, nakazującemu ofiarować Izaaka oraz wiary w to, co niemożliwe, tj. w ocalenie syna. Odkrycie barana, uwikłanego w zaroślach przenosi znaczenie dotychczasowych wydarzeń na jeszcze inny poziom - symboliczny. W idei substytucji zostaje zachowana intencja ofiary z Izaaka, ale jednocześnie zanegowana jest jej materialna dosłowność, gdyż realizuje się ona nie przez zabicie syna, lecz zwierzęcia ofiarnego. Wreszcie przez wielce wymowną nieobecność Izaaka w drodze powrotnej fabuła wykonuje kolejny zaskakujący zwrot, przekształcając się w rytuał przejścia, w ramach którego syn rozstaje się z ojcem, aby rozpocząć własne, samodzielne i dorosłe życie. Nie jest ono możliwe bez przekazu wiary, odbywającego się w dialogu, w którym na pytanie syna, ojciec odsyła go po odpowiedź do Boga, ucząc go słuchania Jego głosu i ufnego poddania się Jego prowadzeniu. 


\section{Summary}

The narrative reading of Genesis 22 consists in following meticulously the plot of the story and its manifold effects on its readers. At the same time it allows to answer a fundamental question which moves this story: how Abraham ought to comprehend God's command to offer his only son as a burnt offering. The patriarch should be praised not for being ready to kill his son, but for submitting himself to the test, in which Isaac has retrieved his own subjectivity and become able to listen directly and personally to God's promises. In this way God will be called not only as the God of Abraham but also as the God of Isaac. 